\title{
PERAN GANDA IBU RUMAH TANGGA (STUDI KASUS PADA TUKANG CUCI MOBIL/MOTOR)
}

\author{
Oleh: Riski Purnama Sari ${ }^{1}$, Andi Agustang² \\ ${ }^{12}$ Program Studi pendidikan Sosiologi Fakultas Ilmu Sosial dan Hukum \\ Universitas Negeri Makassar \\ Email: riskipurnamasari950@gmail.com ${ }^{1}$,andi.agustang@unm.ac.id²
}

\begin{abstract}
Abstrak
Penelitian ini bertujuan untuk mengetahui 1) beban kerja ganda yang dihadapi ibu rumah tangga sebagai tukang cuci mobil/motor, 2) strategi wanita dalam membagi waktu sebagai ibu rumah tangga dan tukang cuci mobil/motor. Jenis penelitian ini merupakan penelitian kualitatif. Jumlah informan dalam penelitian ini sebanyak 6 orang yang ditentukan melalui teknik purposive sampling. Teknik pengumpulan data yaitu observasi, wawancara, dan dokumentasi. Pemeriksaan keabsahan data yang dilakukan dengan menggunakan triangulasi sumber. Hasil penelitian menunjukkan bahwa 1) beban kerja ganda yang dihadapi ibu rumah tangga sebagai tukang cuci mobil/motor ialah dalam melakukan dua peran yaitu ketika harus bekerja dan mengurus anak sekaligus dalam waktu yang bersamaan membuat mereka seringkali merasa kelelahan. 2) strategi wanita dalam membagi waktu sebagai ibu rumah tangga dan tukang cuci mobil/motor antara lain a) mengurus rumah dahulu kemudian berangkat kerja, b) berangkat kerja kemudian mengurus rumah setelah pulang dari kerja, c) berangkat kerja kemudian kembali lagi kerumah saat jam istirahat setelah itu kembali lagi ketempat kerja, dan d) membawa anak ketempat kerja.
\end{abstract}

Kata Kunci: Peran Ganda, Ibu Rumah Tangga, Tukang Cuci Mobil/motor

\section{PENDAHULUAN}

Dalam masyarakat yang melangkah ke zaman baru seperti pada zaman sekarang ini tentunya akan memiliki kebutuhan hidup yang lebih banyak pula. Perubahan pada sistem perekonomian dalam masyarakat akan membawa dampak pada ekonomi keluarga. Oleh karena itu banyak ibu rumah tangga yang terjun langsung untuk mencari nafkah demi memenuhi kebutuhan keluarganya. Mereka pun bisa melakukan pekerjaan apa saja seperti halnya yang dikerjakan oleh laki-laki. Di samping mereka bekerja, tentunya mereka juga mengurus keluarganya dirumah.

(Awaru, 2018) mengemukakan bahwa Partisipasi wanita dalam dunia kerja telah memberikan kontribusi yang besar terhadap kesejahteraan keluarga. Angka wanita pekerja di Indonesia dan juga di negara lain masih akan terus meningkat karena beberapa faktor seperti meningkatnya kesempatan belajar bagi wanita serta memungkinkan mereka untuk dapat menghandle masalah keluarga ataupun masalah kerja sekaligus (Fitriyani, 2019). Peningkatan partisipasi kerja tersebut bukan hanya 
mempengaruhi konstelasi pasar kerja, akan tetapi juga mempengaruhi kesejahteraan wanita itu sendiri dan juga kesejahteraan keluarganya. Wanita yang bekerja akan menambah penghasilan keluarga yang secara otomatis mampu memenuhi kebutuhan hidup serta kualitas gizi dan kesehatan anggota keluarga (Mudzhakar, 2001, h.189)

Keadaan tersebut membuat para wanita memiliki dua peran sekaligus, yaitu peran domestik yang bertugas mengurus rumah tangga dan peran publik yang bertugas diluar rumah atau bekerja untuk memenuhi kebutuhan hidup keluarga. Sebagian besar dari mereka bekerja sebagai buruh yang secara gaji tidak terlalu mencukupi kebutuhan keluarga mereka. (Agustang \& Oruh, 2021)

Nurliana (2017) Bekerjanya kaum wanita diluar atau di level domestik membuat para wanita menjadi lebih maju dan tangguh dalam bergerak maupun berfikir. Seperti pada wanita yang bekerja di salah satu tempat cuci mobil dan motor di Jalan Abdul Kadir, Kelurahan Balang Baru, Kecamatan Tamalate, Kota Makassar. Banyak hal yang dapat dilihat dan sangat menarik ditempat tersebut karena tidak hanya mengandalkan pekerja laki-laki saja tetapi adapula perempuan yang ikut atau turut berproses dalam pekerjaan tersebut.

Tentunya hal itu jarang dilakukan oleh wanita, karena yang sering kita jumpai dalam melakukan pekerjaan tersebut ialah laki-laki. Tetapi hal itu tak dihiraukan oleh mereka para kaum wanita, mereka tetap melakukan pekerjaan itu dikarenakan kebutuhan hidup yang semakin banyak apalagi kehidupan di kota besar yang sangat keras. Apalagi mereka Cuma bisa mengandalkan diri mereka sendiri untuk memenuhi kebutuhannya dan juga anak-anaknya.

Hal ini membuktikan bahwa sosok perempuan ini berbanding terbalik dengan fakta yang ada, karena perempuan biasanya diidentikkan dengan kecantikan, kehalusan, dan kerajinan. Peran ini pun mungkin berbeda dengan peran yang dilakukan oleh wanita-wanita lainnya karena tidak mudah seorang Ibu rumah tangga dalam membagi waktu menjalani dua peran sekaligus. Dan tidak semua Ibu rumah tangga mampu menjalani tanggungjawab yang bisa diemban oleh para Ibu rumah tangga lainnya.

Berdasarkan observasi awal yaitu pada wanita yang bekerja di salah satu tempat cuci mobil dan motor yang melakoni peran ganda sebagai ibu rumah tangga dan juga sebagai karyawan di tempat ia bekerja tersebut. Tak sedikit wanita yang bekerja di lokasi itu, mereka bekerja pada pagi hingga sore hari. Tentu saja mereka juga harus mengurus anak-anaknya disamping mereka juga bekerja diluar rumah agar dapat memenuhi kebutuhan hidupnya.

\section{METODE PENELITIAN}

Jenis penelitian ini adalah kualitatif dengan pendekatan deskiptif. Dalam penelitian ini mengambil lokasi di Jalan Abdul Kadir, Kelurahan Balang Baru, Kecamatan Tamalate, Kota Makassar, Provinsi Sulawesi Selatan. Penelitian ini fokus kepada perempuan pekerja di tempat pencucian mobil/motor, terkait Peran Ganda Ibu 
Rumah Tangga untuk mengetahui beban kerja ganda yang dihadapi ibu rumah tangga sebagai tukang cuci mobil/motor dan strategi wanita dalam membagi waktu sebagai ibu rumah tangga dan tukang cuci mobil/motor. Adapun tahap- tahap penelitian yang dilakukan dalam penelitian ini secara garis besar yaitu tahap pra penelitian, tahap penelitian, dan tahap akhir. Sumber data yang digunakan yaitu sumber data primer dan sumber data sekunder. Jumlah informan sebanyak 6 orang yang dipilih menggunakan teknik purposive sampling. Teknik pengumpulan data dengan metode observasi, wawancara dan dokumentasi (Agustang, 2021). Pengecekan keabsahan data menggunakan teknik triangulasi sumber. Teknik analisis data meliputi reduksi data, penyajian data, dan penarikan kesimpulan.

\section{PEMBAHASAN}

\section{Beban Kerja Ganda yang Dihadapi Ibu Rumah Tangga Sebagai Tukang Cuci Mobil/motor}

Sebagai Ibu rumah tangga yang mengurus anaknya sendiri serta mencari nafkah sendiri juga tentunya tidaklah mudah dilakukan apalagi jika secara bersamaan. Perasaan lelah pastinya dirasakan oleh mereka yang memiliki dua peran dalam keluarganya, seperti pada Ibu-ibu rumah tangga yang bekerja sebagai tukang cuci mobil/motor di Jl. Abdul Kadir, Kelurahan Balang Baru Kecamatan Tamalate, Kota Makassar. Mereka bekerja untuk kelangsungan hidup keluarganya dan juga demi masa depan anak-anaknya, disamping itu mereka juga mengurus rumah tangganya sendiri. Michelle et al (dalam Hidayati 2016) menyatakan bahwa peran ganda disebutkan dengan konsep dualisme cultural, yakni adanya konsep domestik sphere dan publik sphere. Beban ganda adalah partisipasi perempuan menyangkut peran tradisi dan transisi. Peran tradisi atau domestik mencakup peran perempuan sebagai istri, ibu dan pengelola rumah tangga. Sementara peran transisi meliputi pengertian perempuan sebagai tenaga kerja, anggota masyarakat dan manusia pembangunan. Pada peran transisi perempuan sebagai tenaga kerja turut aktif dalam kegiatan ekonomis (mencari nafkah) di berbagai kegiatan sesuai dengan keterampilan dan pendidikan yang dimiliki serta lapangan pekerjaan yang tersedia.(Randall dan Scott 1987)

Peran ganda perempuan ialah peran perempuan di satu pihak keluarga sebagai pribadi yang mandiri, ibu rumah tangga, dan mengasuh anak-anak. Serta di pihak lain sebagai anggota masyarakat, sebagai pekerja dan sebagai warga Negara yang dilaksanakan secara seimbang (Wibowo dan Gianawati 2015). Seperti pada informan yang peneliti dapatkan dilapangan bahwa mereka melakukan pekerjaan rumah juga mengurus anak-anaknya apabila mereka berada dirumah, sedangkan jika mereka berada diluar rumah mereka akan bekerja sebagai tukang cuci mobil/motor. Perempuan dianggap melakukan peran ganda apabila ia bertanggung jawab terhadap tugas-tugas domestik yang berhubungan dengan rumah tangga seperti membersihkan rumah, memasak, merawat anak-anak, serta ketika perempuan juga bertanggung jawab atas publik yang berkaitan dengan kerja di sektor publik yakni bekerja diluar rumah dan 
bahkan seringkali berperan sebagai pencari nafkah utama. Perempuan mempunyai dua peranan yaitu sebagai istri atau ibu rumah tangga yang melakukan pekerjaan rumah tangga yaitu pekerjaan produktif yang tidak langsung menghasilkan pendapatan dan sebagai pencari nafkah yang langsung menghasilkan pendapatan (Pudjiwati. 1985). Setiap peran yang dimiliki oleh perempuan akan memiliki konsekuensinya sendiri. Jika seorang pekerja sebagai tukang cuci mobil/motor seperti pada informan yang diteliti tentunya resiko dari pekerjaan itu akan menimbulkan beban tersendiri dikarenakan ia juga harus mengurus rumah tangga dan anak-anaknya dan pastinya akan berdampak juga pada pertumbuhan anak-anaknya dikarenakan ia mendapatkan perhatian yang kurang oleh Ibunya karena sibuk bekerja. Hal itu tentunya membuat Ibu dan anak jarang bertemu sehingga anak hanya di perhatikan saat Ibunya berada dirumah.

Dalam menjalankan peran domestik dan publiknya seluruh informan dapat dikategorikan memiliki manajemen rumah tangga yang baik meskipun kadang-kadang kegiatan domestik dan publiknya terdapat sedikit hambatan kecil dan sering mengalami kelelahan dan stres. Kondisi itu muncul ketika adanya beban yang berlebih dari masingmasing peran. Keluarganya pun tidak ada yang merasa keberatan dan menolak adanya peran ganda tersebut dikarenakan ia dapat mengurus rumah tanggah dan mengasuh anak-anaknya dengan baik meskipun waktu mereka bersama dirumah lebih sedikit. (Arif, 2019)

Dalam penelitian ini terlihat bahwa sang ibu lah yang menanggung seluruh beban yang ada dalam rumah. Beban ganda ini tidak hanya terjadi dirumah atau di ranah domestik saja, tetapi juga bisa terjadi terjadi di ranah publik dimana ibu bekerja kerap kali harus membawa anaknya ke tempat bekerja. Kondisi ini jelas saja menyebabkan beban ganda yang biasa terjadi dirumah atau ranah domestik ternyata ikut bertransisi ke ranah publik yang memaksa ibu bekerja ganda dan berbeban ganda dalam waktu yang bersamaan.

Dalam teori feminisme liberal yang mendasarkan pemikirannya pada konsep liberal yang menekankan bahwa wanita dan pria diciptakan sama dan mempunyai hak yang sama dan juga harus mempunyai kesempatan yang sama (Rokhmansyah, 2016), berkaitan dengan Ibu-ibu rumah tangga yang bekerja tersebut bahwa mereka bisa melakukan pekerjaan apa saja dengan baik bahkan mereka juga bisa mengurus rumah tangga serta anak-anaknya bahkan dengan waktu yang bersamaan. Kini perempuan telah mempunyai kekuatan dari segi pendidikan dan pendapatan, serta saatnya kini perempuan bebas berkehendak tanpa tergantung pada lelaki. Hal ini dibuktikan dengan informan peneliti yakni para ibu rumah tangga yang bekerja sebagai tukang cuci mobil/motor. Mereka juga bisa mengerjakan pekerjaan yang seharusnya dikerjakan oleh laki-laki, tetapi mereka juga sanggup mengerjakan pekerjaan tersebut. Menjalankan dua atau lebih peran sekaligus bukanlah hal yang mudah, tentunya ada rasa lelah yang dirasakan. Akar teori ini bertumpu pada kebebasan dan kesetaraan rasionalitas. Perempuan adalah makhluk rasional, kemampuannya sama dengan lakilaki sehingga harus diberi hak yang sama juga dengan laki- laki (Polii, 2012). Oleh 
karena itu pada abad 19 banyak upaya memperjuangkan kesempatan hak sipil dan ekonomi bagi perempuan, hingga akhirnya pada saat ini banyak ditemukan perempuan yang bekerja di bidang apapun.

Dari hasil pemikiran diatas, terlihat jelas bahwa semangat para ibu yang bekerja tidak akan surut dikarenakan mereka selalu mengingat masa depan anak-anaknya dan ingin memberikan yang terbaik untuk anak-anaknya meskipun waktu mereka untuk bersama dirumah tidak terlalu banyak dikarenakan ia harus bekerja. Beban kerja ganda yang dihadapi para informan tidak membuat mereka untuk berputus asa dalam melakukan dua peran sekaligus, karena menurutnya ini sudah menjadi jalan hidupnya jadi harus dijalani dengan sabar dan ikhlas.

\section{Strategi Wanita Dalam Membagi Waktu Sebagai Ibu Rumah Tangga dan Tukang Cuci Mobil/motor}

Seorang perempuan yang sudah berumah tangga berperan untuk mengurus rumah serta mendidik anak-anaknya. Namun bagi perempuan yang telah berumah tangga dan juga bekerja di sektor publik kerap kali kesulitan membagi waktu untuk mengerjakan semua kewajibannya. Salah satu kesulitan yang dialami oleh beberapa pekerja wanita di tempat cuci mobil/motor yaitu sulitnya mengurus anak, misalnya di waktu pagi seorang ibu terkadang kebingungan antara harus segera bekerja atau mrngurus anak terlebih dahulu. Mengurus anak merupakan kewajiban seorang ibu, namun adakalanya mereka harus mengorbankan saat-saat penting seperti itu yaitu ketika seorang ibu rumah tangga harus pergi bekerja karena hanya ia yang merupakan tulang punggung bagi anak-anaknya. Sebagai perempuan bekerja maka tingkat partisipasinya di publik tidaklah mudah. Selain karena didasari oleh berbagai alasan yang melatarbelakangi dirinya bekerja juga dipengaruhi oleh suatu proses pengambilan keputusan dan pertimbangan untuk memasuki dunia kerja. Daulay (2015) mengemukakan bahwa perempuan harus mempertimbangkan kembali akan pengasuhan anak-anaknya apabila dirinya yang berstatus sebagai ibu juga sebagai perempuan bekerja diluar rumah.

Dalam menjalankan peran ganda tentunya para ibu tangga yang juga bekerja pastinya kerap akan merasa kewalahan, maka dari itu mereka harus mengatur strategi agar dapat mengoptimalkan waktu dan pekerjaannya berjalan dengan baik. Seperti yang dilakukan para informan dalam mengatur strategi yaitu dengan menjadwalkan pekerjaan mana yang terlebih dahulu akan ia kerjakan. Adapun beberapa informan yang mengatur strategi seperti: (1) Mengerjakan pekerjaan rumah terlebih dahulu pada pagi hari sebelum berangkat kerja, yaitu membersihkan rumah, mencuci pakaian, memasak, bahkan mengurus anak-anak, setelah semuanya selesai barulah ia berangkat bekerja. Hal itu dilakukan agar ketika bekerja ia tidak memikirkan hal-hal lain lagi, atau dengan kata lain pikirannya tidak terbagi-terbagi lagi antara bekerja dengan mengurus rumah dan anak-anak; sedangkan beberapa informan juga melakukan strategi yang ke (2) Berangkat kerja pada pagi hari kemudian membereskan rumah nanti ketika sepulang 
dari kerja, juga mengurus anak-anaknya pada malam hari. Jadi pagi hingga sore hari ia lebih fokus untuk bekerja; strategi berikutnya juga kerap dilakukan oleh beberpa informan yaitu (3) Berangkat kerja pada pagi hari dan pada saat siang hari atau jam istirahat ia menyempatkan diri untuk pulang kerumahnya mengurus anak-anaknya, memasak, menyapu rumah, setelah itu ia kembali lagi ketempat kerja, hal itu dilakukan karena jarak rumah dan tempat kerja informan tidak terlalu jauh; dan strategi yang terakhir juga biasa dilakukan yaitu (4) Dengan membawa anaknya ke tempat kerja agar tidak was-was ketika meninggalkan anak dirumah apalagi jika anaknya masih kecil maka ia akan membawanya juga. Dari keempat strategi diatas dapat dikatakan bahwa para informan dapat mengatur waktu antara bekerja dengan mengurus rumah tangga dan anak-anaknya meskipun terkadang mereka juga mengalami kelelahan.

Maka dari itu perempuan yang bekerja mempunyai dilemanya sendiri mengenai pembagian waktu di keluarga dan juga pekerjaannya (Ramadhani, 2016). Tetapi hal itu tetap dijalaninya dan terus berusaha melakukan yang terbaik untuk keluarganya, karena jika mereka tidak bekerja maka tidak ada penghasilan yang akan didapatkan untuk memenuhi kebutuhan dalam kehidupan sehari-hari. Ditambah lagi para informan merupakan ibu rumah tangga yang sudah tidak memiliki suami (janda) jadi mereka harus betul-betul berusaha untuk menghidupi dirinya dan anak-anaknya. Tetapi masalah waktu memang sangat dirasakan oleh ibu yang bekerja karena sebagai seorang ibu rumah tangga ia tidak dapat melepaskan kewajibannya terhadap rumah tangga, keluarga, dan masyarakat. Manajemen waktu dalam mengurus rumah tangga dan bekerja merupakan salah satu kesulitan yang paling sering dihadapi. Perempuan harus dapat memainkan peran sebagai ibu yang bijak dan sabar memperhatikan dan mengikuti perkembangan anak-anak serta bertanggung jawab untuk mengurus segala sesuatu keperluan rumah tangga. Di tempat kerja mereka juga mempunyai komitmen dan tanggung jawab terhadap pekerjaan yang telah dipercayakan kepada mereka. Dengan demikian ibu yang bekerja harus mengatur waktunya dengan terstruktur agar tugasnya sebagai seorang ibu rumah tangga dan pekerja dapat diperankan dengan baik.

Dari hasil pemikiran diatas, dapat dikatakan bahwa strategi para informan dalam mengatur waktu antara bekerja dengan mengurus rumah dapat mereka jalankan dan menyeimbangkannya dengan baik. Meskipun pekerjaannya hanya sebagai tukang cuci mobil/motor tetapi itu tidak menghalanginya dalam mengurus rumah dan mengasuh anak- anaknya. Berbagai strategi dapat dilakukan oleh para informan dalam mengatur waktu, walaupun strategi yang mereka lakukan tersebut berbeda-beda. Karena kemampuan tiap manusia juga berbeda, maka dari itu beragam cara pula strategi yang peneliti dapatkan dalam penelitian ini.

\section{PENUTUP}

Setelah penulis menyajikan hasil penelitian dan pembahasan pada bab sebelumnya, maka pada bab ini penulis akan menyajikan beberapa kesimpulan berdasarkan rumusan masalah yang diangkat pada penelitian ini, yaitu: a)Beban kerja 
ganda yang dihadapi Ibu rumah tangga sebagai tukang cuci mobil/motor berdasarkan hasil penelitian ialah dalam melakukan dua peran yaitu ketika harus bekerja dan mengurus anak sekaligus dalam waktu yang bersamaan membuat mereka seringkali merasa kelelahan. Tentunya hal itu pasti akan mereka rasakan, tetapi itu tidak menyurutkan semangat para Ibu yang bekerja dikarenakan mereka selalu memikirkan masa depan anak- anaknya. Meskipun mereka adalah tulang punggung untuk anakanaknya tetapi mereka juga tidak lalai dalam mengurus rumah, memasak, dan mengasuh anak. Hal ini harus mereka jalani karena mereka sudah tidak memiliki suami, maka dari itu mereka lah yang harus terjun langsung untuk mencari nafkah. b) Strategi wanita dalam membagi waktu sebagai Ibu rumah tangga dan tukang cuci mobil/motor berdasarkan hasil penelitian terdapat 4 strategi yang dilakukan para informan yaitu: (1) Mengerjakan pekerjaan rumah terlebih dahulu pada pagi hari sebelum berangkat kerja, (2) Berangkat kerja pada pagi hari kemudian membereskan rumah nanti ketika sepulang dari kerja, juga mengurus anak-anaknya pada malam hari, (3) Berangkat kerja pada pagi hari dan pada saat siang hari atau jam istirahat ia menyempatkan diri untuk pulang kerumahnya mengurus anak-anaknya, memasak, menyapu rumah, setelah itu ia kembali lagi ketempat kerja, (4) Dengan membawa anaknya ke tempat kerja agar tidak was-was ketika meninggalkan anak dirumah apalagi jika anaknya masih kecil.

\section{DAFTAR PUSTAKA}

Agustang, A. (2021, January 22). Filosofi Research Dalam Upaya Pengembangan Ilmu. https://doi.org/10.31219/osf.io/9n6za

Agustang, A., \& Oruh, S. (2021). KESEJAHTERAAN PSIKOLOGIS (studi Pada Dewasa Madya Yang Belum Menikah Di Kota Makassar).

Akbar, H., Oruh, S., \& Agustang, A. (2021). Indeks Prediktif Kejadian Demam Berdarah Dengue (DBD) Berbasis Perilaku Sosial Masyarakat Di Kabupaten Indramayu. Jurnal Kesehatan, 14(2 SE-), 76-82. https://doi.org/10.32763/juke.v14i2.289

Arif, Z. Z. (2019). peran ganda perempuan dalam keluarga pespektif feminis muslim Indonesia. Indonesian Journal of Islamic Law, 1(2), 97-126.

Damayanti, R. R., \& Awaru, A. O. T. (2018). PEREMPUAN PENJUAL IKAN DI AWERANGE DESA BATUPUTE KECAMATAN SOPPENG RIAJA

KABUPATEN BARRU (Suatu Kajian Sosiologi Gender). Jurnal Sosialisasi: Jurnal Hasil Pemikiran, Penelitian Dan Pengembangan Keilmuan Sosiologi Pendidikan, 131-136.

Daulay. (2015). Perempuan Di Sektor Publik. Tiara Wacana.

Fitriyani, F. (2019). Peran Perempuan dalam Upaya Meningkatkan Perekonomian Rumah Tangga Ditinjau dari Ekonomi Syariah (Studi pada Pedagang di Pasar Tradisional Kabupaten Lebak). UNIVERSITAS ISLAM NEGERI SERANG BANTEN.

Hidayati, N. (2016). Beban ganda perempuan bekerja (antara domestik dan publik). Muwazah: Jurnal Kajian Gender, 7(2).

Mudzhakar, H. . A. (2001). Wanita Dalam Masyarakat Indonesia. Sunan Kalijaga Press.

Nurliana, N. (2017). Wanita Karir Menurut Hukum Islam. Al-Fikra: Jurnal Ilmiah 
Pinisi Journal Of Sociology Education Review; Vol. 1; No. 2; Juli 2021

Halaman 106-113

Keislaman, 9(1), 70-100.

Oruh, S., Agustang, A., \& Bagu, A. A. (2017). KEJADIAN HEROPNAM GANGGUAN JIWA DAN FAKTOR YANG MEMPENGARUHI PADA RUMAH SAKIT KHUSUS DAERAH DADI PROVINSI SULAWESI SELATAN.

Oruh, S., \& AGUSTANG, A. (2019). PENGARUH PENGETAHUAN KELUARGA, STIGMA MASYARAKAT DAN KEPATUHAN MINUM OBAT TERHADAP KEKAMBUHAN PENYAKIT GANGGUAN JIWA DI KOTA MAKASSAR.

Hariani, H., Oruh, S., \& Mustari, N. (2021). GAMBARAN POLA ASUH ANAK PADA IBU YANG BEKERJA DI KELURAHAN KARANG ANYAR KOTA MAKASSAR. Media Keperawatan: Politeknik Kesehatan Makassar, 12(1), 1-6.

Mukti, I., Oruh, S., \& Agustang, A. (2021). Efek Pemberitaan Kekerasan Di Media Sosial Terhadap Citra Negatif Kota Makassar. JISIP (Jurnal Ilmu Sosial Dan Pendidikan), 5(4).

Polii, I. J. (2012). Aspirasi Feminisme Liberal Beretika dalam Dwilogi Novel Padang Bulan dan Cinta di Dalam Gelas Karya Andrea Hirata (Studi Pemikiran Pengarang Terkait Eksistensi Perempuan).

Pudjiwati. (1985). Bila Suami Istri Bekerja. Kanisius.

Ramadhani, N. (2016). Implikasi peran ganda perempuan dalam kehidupan keluarga dan lingkungan masyarakat. Sosietas, 6(2).

Randall, C., \& Scott, C. (1987). Sociology of marriage and the family: Gender, love, and property. Chicago: Nelson Hall.

Rokhmansyah, A. (2016). Pengantar gender dan feminisme: Pemahaman awal kritik sastra feminisme. Garudhawaca.

Sugiyono, D. (2013). Metode penelitian pendidikan pendekatan kuantitatif, kualitatif dan $R \& D$. Alfabeta.

Wibowo, S. A., \& Gianawati, N. D. (2015). Peran Ganda Ibu Rumah Tangga dalam Memenuhi Kebutuhan Keluarga.

Oruh, S. (2022, January 4). STRATEGI PENGEMBANGAN SUMBER DAYA MASYARAKAT KEPULAUAN YANG UNGGUL MENUJU SOCIETY 5.0. https://doi.org/10.17605/OSF.IO/SP42D

Oruh, S. (2022, January 4). Supplemental materials for preprint: KAU MAU KEMANA (Refleksi Sosiologis terhadap Integritas Upaya Kesehatan Jiwa). https://doi.org/10.17605/OSF.IO/CP39Z

Oruh, S., \& Agustang, A. (2022, January 4). KESEJAHTERAAN PSIKOLOGIS (Studi Pada Dewasa Madya yang Belum Menikah di Kota Makassar). https://doi.org/10.17605/OSF.IO/ZUSKV

Oruh, S., \& Agustang, A. (2022, January 4). PENGARUH PENGETAHUAN KELUARGA, STIGMA MASYARAKAT DAN KEPATUHAN MINUM OBAT TERHADAP KEKAMBUHAN PENYAKIT GANGGUAN JIWA DI KOTA MAKASSAR. https://doi.org/10.17605/OSF.IO/K4VMP

Agustang, A., \& Oruh, S. (2022, January 4). HEGEMONIC SOCIAL RELATION A Study of Sociology on Outsourcing Practice. https://doi.org/10.17605/OSF.IO/PJM3A

Oruh, S., Agustang, A., \& Agustang, A. D. M. P. (2021, December 21). SOCIAL DETERMINANTS OF COMMUNITY HEALTH WITH THE EVENT OF DIABETES MELLITUS (Study of Health Sociology in Makassar City). https://doi.org/10.31219/osf.io/4qvxf

Tilome, A. A., Agustang, A. D. M. P., \& Agustang, A. (2021, December 16).

PERTUKARAN SOSIAL ELIT POLITIK DALAM PEMILIHAN KEPALA

DAERAH DI PROVINSI GORONTALO. https://doi.org/10.31219/osf.io/6tu79 